\title{
Inclusive conflict? Competitive clientelism and the rise of political violence
}

\author{
Clionadh Raleigh ${ }^{1 \star}$ (D), Hyun Jin Choi $^{2}$ and Daniel Wigmore-Shepherd ${ }^{1,3}$ \\ ${ }^{1}$ School of Global Studies, University of Sussex, Brighton, United Kingdom, ${ }^{2}$ Department of Political Science, CHA Kyung \\ Hee University, Seoul, South Korea and ${ }^{3}$ ORB International, London, United Kingdom \\ ${ }^{\star}$ Corresponding author. Email: clionadh.sussex@gmail.com
}

(Received 7 May 2020; revised 14 March 2021; accepted 15 March 2021; first published online 18 May 2021)

\begin{abstract}
Conflict across African states has often been linked to ethnic-based biases in government, and exclusive policies. However, the domestic politics of developing states, and the elites who contest for power therein, have often been overlooked when explaining the patterns and risk of disorder and violence. We consider how African leaders practice politics in whom to represent, and at what level. These choices have consequences as how regimes accommodate political elites creates different competitive conditions which, in turn, create incentives and opportunities for political violence. Using a dataset on cabinet appointments over twenty years, we find that high levels of elite political inclusion and mal-apportionment in positions is consistently associated with increases in non-state violence. Power distribution levels among those groups included in senior positions account for more political violence than that which stems from exclusive politics.
\end{abstract}

Keywords: Africa; Conflict; Exclusion; Domestic Politics

\section{Introduction}

Recent conflict research has explained the rise and persistence of civil wars through exclusive and biased political settlements and institutional arrangements. Regime replacement and civil war is robustly associated with political exclusion ${ }^{1}$ and horizontal and vertical inequalities in representation. ${ }^{2}$ Indeed, with the adoption of democratic and participatory institutions, civil wars have declined precipitously across Africa. Almost all African states are now characterised as semidemocracies, electoral autocracies, hybrid regimes, or 'competitive autocracies'. ${ }^{3}$ These same governments adopt institutions like cabinets, parliaments, and independent judiciaries to distribute power, encourage political competition through elections and opposition parties, and check the

\footnotetext{
${ }^{1}$ Lars-Erik Cederman, Andreas Wimmer, and Brian Min, 'Why do ethnic groups rebel? New data and analysis', World Politics, 62:1 (2009), pp. 87-119; Philip Roessler, 'The enemy within: Personal rule, coups, and civil war in Africa', World Politics, 63:2 (2011), pp. 300-46; Lars-Erik Cederman, Kristian Skrede Gleditsch, and Halvard Buhaug, Inequality, Grievances, and Civil War (Cambridge: Cambridge University Press, 2013).

${ }^{2}$ Gudrun Ostby, 'Inequalities, the political environment and civil conflict: Evidence from 55 developing countries', in F. Stewart (ed.), Horizontal Inequalities and Conflict (London: Palgrave Macmillan, 2008), pp. 136-59; Halvard Buhaug, Lars-Erik Cederman, and Jan Ketil Rod, 'Disaggregating ethno-nationalist civil wars: A dyadic test of exclusion theory', International Organization, 62:3 (2008), pp. 531-51.

${ }^{3}$ Barbara Geddes, Joseph Wright, and Erica Frantz, How Dictatorships Work: Power, Personalization, and Collapse (Cambridge: Cambridge University Press, 2018).

() The Author(s), 2021. Published by Cambridge University Press on behalf of the British International Studies Association. This is an Open Access article, distributed under the terms of the Creative Commons Attribution licence (http://creativecommons.org/licenses/by/4.0/), which permits unrestricted re-use, distribution, and reproduction in any medium, provided the original work is properly cited.
} 
power of the executive through term limits. ${ }^{4}$ As a result, African states are strongly inclusive in senior, key institutions. ${ }^{5}$ Governments with autocratic practices and 'functional' quasi-democratic institutions ${ }^{6}$ aim to integrate, rather than sideline ethno-regional political communities.

However, 'inclusive' governments are not peaceful; most African states experience some form of sustained political violence by militias and non-state groups after the adoption of democratising institutions. The political violence patterns in such states rarely assume a 'civil war' form, where at least one main armed group has an intention of removing the regime. This political violence involves a myriad of political motives, patrons, and strategies against the state, civilians, and armed non-state groups. Common forms include threatening voters, competing with other political elites, providing security for a defined group, harassing other identity groups, operating as substitute police or military enforcers and engaging in local rent seeking. ${ }^{7}$ This type of violence has drastically increased in the past two decades, while rebel violence and insurgencies have largely declined, and this change in the main modality of conflicts suggests that institutional changes may depress the likelihood of one form of conflict, like civil wars, while increasing the incentives for others. The presence of inclusive institutions and widespread group representation may be important contexts to explain why civil wars have abated, but these factors do not have the same influence on the occurrence of political violence across states. It is clear that conflict agents are adapting to different domestic political arrangements and distributions of power.

How does the composition of an inclusive government influence conflict? We address how levels and variants of political representation at senior levels of government are associated with the form and occurrence of political violence. Our work is part of a longer tradition of explaining political violence patterns and forms through the distribution of power within states, and is a continuation and refinement of explanations where violence is used as a strategy through which political groups compete with each other. We argue that violence adapts to the distribution of power and the dominant forms of political competition. For example, with the adoption of inclusive, formal political institutions, African regimes widened the composition of group representation in formal offices. But these same institutions and elites have served to promote and propagate internal regime practices that determine and secure appointments, rents, and access to power.

These practices have increased levels of 'competitive clientelism' at the senior scales of government, where groups and their elite representatives use political violence against the state and each other to secure access to authority, positions, and proximity to the leader. In these inclusive and competitive regimes, levels of absolute representation and levels of political exclusion are not closely related to conflict rates. Instead, mal-apportionment of positions between groups in formal roles is a key measure of the competitive context that encourages groups and elites to engage in violence. The use of conflict is a key strategy to increase a group and elite's relative leverage in their competition to secure positions, authority, and rents.

We develop new theoretical avenues and support our hypotheses by using data on cabinet representation in governments on a monthly scale. The African Cabinet and Political Elite Data Project (ACPED) measures how groups and elites are accommodated in government by compiling detailed information on cabinet appointments and ministerial characteristics, by month, over the past twenty years. ${ }^{8}$ We compare the characteristics and rates of time varying senior cabinet representation to political violence rates and forms across African states. These

\footnotetext{
${ }^{4}$ Nic Cheeseman, Gabrielle Lynch, and Justin Willis, 'Decentralisation in Kenya: The governance of governors', The Journal of Modern African Studies, 54:1 (2016), pp. 1-35.

${ }^{5}$ Clionadh Raleigh and Daniel Wigmore-Shepherd, 'Elite coalitions and power balance across African regimes: Introducing the African cabinet and political elite data project (ACPED)', Ethnopolitics (2020); Patrick Francois, Ilia Rainer, and Francesco Trebbi, 'How is power shared in Africa?', Econometrica, 83:2 (2015), pp. 465-503.

${ }^{6}$ David Art, 'What do we know about authoritarianism after ten years?', Comparative Politics, 44:3 (2012), pp. 351-73.

${ }^{7}$ Clionadh Raleigh, 'Pragmatic and promiscuous: Explaining the rise of competitive political militias across Africa', The Journal of Conflict Resolution, 60:2 (2016), pp. 283-310.

${ }^{8}$ Raleigh and Wigmore-Shepherd, 'Elite coalitions and power balance across African regimes'.
} 
cabinet, political elite, and group representation data improve significantly on the existing measures of group representation in government, which provide overly static, aggregated community positioning in central government or annual aggregate information on cabinet positions from the past. ${ }^{9}$ These previous data projects largely overlooked the changes in elite politics, appointments, and government strategies of inclusion, which, we believe, underscore the competitive clientelism that has arisen across African states.

Using these data, we develop a compelling explanation for increased political violence through competitive clientelism among group representatives and senior elites. We demonstrate that leaders are dependent on mutually beneficial political alliances made with a wide range of subnational elites, and through this inclusion process, many political elites are granted preferential access to political and economic organs of the state. ${ }^{10}$ This process of mutually beneficial bargaining 'among contending elites ${ }^{11}$ is associated with considerable regime longevity ${ }^{12}$ and is referred to as the 'politics of survival' ${ }^{13}$ or the 'political marketplace'. ${ }^{14}$ But such transactional politics are not stable or without conflict. Many African states suffer from representation volatility and imbalance at the senior levels of government, and those variations at the elite level are closely correlated to the occurrence of political violence throughout the state. As elites and their supporters are keenly aware of the competitive and transactional environment that inclusive political representation has generated, they are willing and able to use political violence as an effective tool of competition, political manipulation, and intra-elite negotiation. Our findings reflect pragmatic political calculations: in states with high levels of ethnic inclusion, if representatives of large or wealthy communities fail to acquire a due share of ministerial positions, higher levels of political violence are expected. Similarly, if small communities acquire too much power relative to their size, higher levels of political violence are also expected.

The larger significance of these findings is that we show that conflict arises from a contest for power, not its absence; and rather than a resort of excluded groups, political violence is mainly used by groups who have high levels of inclusion. Groups and elites engage in conflict to increase their power share, even if they have a highly favourable proportion of senior authority. Therefore, the imbalance of power between included senior elites is a better predictor of which countries are at risk for increased political violence than theories about ethnic exclusion.

\section{Exclusion, grievances, and institutional corrections}

Many of Africa's governments are regarded as active autocracies, ${ }^{15}$ with adjustments for the particular institutional and personalist characteristics. ${ }^{16} \mathrm{~A}$ common presumption is that governments in these states have an unequal representation of groups in a patronage-based system, active marginalisation of minority groups, with disproportional authority going to a leader's home group and region. ${ }^{17}$ In such cases, political exclusion is a proxy for

\footnotetext{
${ }^{9}$ Francois, Rainer, and Trebbi, 'How is power shared in Africa?'.

${ }^{10}$ Leonardo Rafael Arriola and Martha Johnson, 'Ethnic politics and women's empowerment in Africa: Ministerial appointments to executive cabinets', American Journal of Political Science, 58:2 (2014), pp. 495-510.

${ }^{11}$ Jonathan Di John and James Putzel, Political Settlements (Birmingham: GSDRC, 2009).

${ }^{12}$ Jaimie Bleck and Nicolas Van de Walle, Electoral Politics in Africa since 1990: Continuity in Change (Cambridge: Cambridge University Press, 2018).

${ }^{13}$ Joel S. Migdal, Strong Societies and Weak States: State-Society Relations and State Capabilities in the Third World (Princeton, NJ: Princeton University Press, 1988).

${ }^{14}$ Alex de Waal, The Real Politics of the Horn of Africa: Money, War and the Business of Power (Cambridge: Polity Press, 2015).

${ }^{15}$ Geddes, Wright, and Frantz, How Dictatorships Work.

${ }^{16}$ Steven R. Levitsky and Lucan A. Way, 'Elections without democracy: The rise of competitive authoritarianism', Journal of Democracy, 13:2 (2002), pp. 51-65.

${ }^{17}$ Patrick Chabal and Jean-Pascal Daloz, Africa Works: Disorder as Political Instrument (Oxford: The International African Institute in association with James Currey, 1999); Michael Bratton and Nicolas Van de Walle, 'Neopatrimonial regimes and
} 
grievance $^{18}$ and a necessary and sufficient prerequisite for political violence. But assumptions about the exclusive characteristics of African autocracies has stifled inquiry into how representation transcends measures of inclusion and exclusion, and how regimes have built highly representative government institutions over the past twenty years.

An 'African institutionalism' literature argues that 'formal institutional rules are coming to matter much more than they used to ${ }^{19}$ in contrast to an 'almost [exclusive] focus on ... clients and patrons ... which ... largely ignored the institutional environment in which the transactions between them take place'. ${ }^{20}$ Regimes have engaged more and varied political elites in legislatures ${ }^{21}$ and cabinets; institutional devices, such as election committees, that can mediate political outcomes are more widely present; ${ }^{22}$ leaders are curtailed by presidential term limits; ${ }^{23}$ decentralisation projects have curbed personalist power; ${ }^{24}$ regimes have to engage with inter-regional and group integration systems; ${ }^{25}$ and party systems within regimes nominally act as a system of checks on the executive. ${ }^{26}$

But autocracy and 'new institutionalisation' research findings diverge in their interpretation of modern African regimes. One argues that institutionalisation is a steady path to representative democracy, highlighting how the state increasingly mediates and limits personalist practices and engages in extensive inclusive representation. Due to these constraints, the power balance favours voters and elites as constituencies, who in turn have more opportunities to exercise power. A second, more functionalist, literature suggests that the greater role of (quasi-) formal institutions is not evidence of a democratic progress. It maintains that the inner workings of African power adapt to the new reality and remain unaltered, ${ }^{27}$ and institutions are adopted to support regimes and leaders, rather than as a constraint to central authorities. ${ }^{28}$ Regimes incorporate an extensive range of ethnopolitical representatives in order to promote regime survival, rather than representing alternative power holders. While nominally adopting democratic practices, regimes and leaders keep power by spreading it around'; ${ }^{29}$ integrating politicians from different ethnic groups into their coalitions has allowed African leaders to effectively consolidate power. ${ }^{30}$ Leaders extend and consolidate their

political transitions in Africa', World Politics, 46:4 (1994), pp. 453-89; Donald Rothchild, 'Ethnic bargaining and state breakdown in Africa', Nationalism and Ethnic Politics, 1:1 (1995), pp. 54-72.

${ }^{18}$ Macarten Humphreys and Jeremy M. Weinstein, 'Who fights? The determinants of participation in civil war', American Journal of Political Science, 52:2 (2008), pp. 436-55.

${ }^{19}$ Daniel N. Posner and Daniel J. Young, 'The institutionalization of political power in Africa', Journal of Democracy, 18:3 (2007), pp. 126-40.

${ }^{20}$ Mike Muller, 'Parish pump politics: The politics of water supply in South Africa', Progress in Development Studies, 7:1 (2007), pp. 33-45.

${ }^{21}$ Anja Osei and Thomas Malang, 'Party, ethnicity, or region? Determinants of informal political exchange in the parliament of Ghana', Party Politics, 24:4 (2018), pp. 410-20.

${ }^{22} \mathrm{Nic}$ Cheeseman, 'African elections as vehicles for change', Journal of Democracy, 21:4 (2010), pp. 139-53.

${ }^{23}$ Posner and Young, 'The institutionalization of political power in Africa'; Filip Reyntjens, 'The struggle over term limits in Africa: A new look at the evidence', Journal of Democracy, 27:3 (2016), pp. 61-8.

${ }^{24}$ Alex Dyzenhaus, 'Decentralisation: Accountability in local government', in Nic Cheeseman (ed.), Institutions and Democracy in Africa: How the Rules of the Game Shape Political Developments (Cambridge: Cambridge University Press, 2018), pp. 327-50; Charles M. Fombad, 'Constitutional entrenchment of decentralization in Africa: An overview of trends and tendencies', Journal of African Law, 62:2 (2018), pp. 175-99.

${ }^{25}$ Dyzenhaus, 'Decentralisation'.

${ }^{26}$ Steven R. Levitsky and Lucan A. Way, 'The durability of revolutionary regimes', Journal of Democracy, 24:3 (2013), pp. 5-17; Dan Paget, 'The Rally-Intensive Ground Campaign: Electioneering and Party Adaptation in Tanzania' (PhD dissertation, University of Oxford, 2018).

${ }^{27}$ Bleck and Van De Walle, Electoral Politics in Africa since 1990.

${ }^{28}$ Beatriz Magaloni, 'Credible power-sharing and the longevity of authoritarian rule', Comparative Political Studies, 41:4-5 (2008), pp. 715-41.

${ }^{29}$ Stephen Haber, 'Authoritarian government', in Donald A. Wittman and Barry R. Weingast (eds), The Oxford Handbook of Political Economy (Oxford: Oxford University Press, 2006).

${ }^{30}$ Jean-Francois Bayart, The State in Africa: The Politics of the Belly (London: Longman, 1993); Rothchild, 'Ethnic bargaining and state breakdown in Africa'. 
regimes by co-opting elites and their constituencies, and endanger regimes if they did not integrate other powerful domestic agents to secure continued power and extend authority across the state. ${ }^{31}$

A regime's ruling coalition adapts to their state's social heterogeneity, but the lack of absolute ethnic or regional majorities in many African countries means that leaders cannot rely on their own groups for political support to maintain power. ${ }^{32}$ To acquiesce to co-ethnics or demographic minorities would place leaders in a weak, vulnerable position. ${ }^{33}$ For regimes in politically heterogeneous societies, cross-group inclusive coalitions are the best strategy for leaders to secure a majority or plurality. ${ }^{34}$

Regime maintenance strategies guide leaders on ministerial appointments, dismissals, and reshuffles. ${ }^{35}$ A dramatic increase in ministerial posts during periods of democratisation allowed leaders to redistribute material and symbolic rents from the centre and strengthen ties with their regional and political constituencies. ${ }^{36}$ In these cases, large coalitions are optimal and serve as an effective strategy for facilitating intra-elite accommodation and warding off forced removal. Creating an inclusive and expansive coalition that can co-opt potential political opponents and their constituents can limit the capabilities of opposition coalitions and further enhance the incumbent's chance of re-election. In short, regime survival in a changing political landscape necessitates an inclusive, transactional approach to elite and group representation. The implication of such functionalist political change is that representation has an alternative logic other than power sharing and operating as a check on the executive, and democratisation is an insufficient explanation for widespread senior representation across African governments.

\section{Representation, communities, and elites}

But who and what is necessary to represent? Politics in Africa remains strongly shaped by ethnopolitical and regional identities due to bloc interests, political support, and patronage. ${ }^{37}$ Ethnic groups can provide 'a form of minimum winning coalition, large enough to secure benefits in the competition for spoils but also small enough to maximize the per capita value of these benefits $;{ }^{38}$ bloc interests prevent non-members from participating in the allocation of political goods. ${ }^{39}$

\footnotetext{
${ }^{31}$ Douglass C. North, John Joseph Wallis, and Barry R. Weingast, Violence and Social Orders: A Conceptual Framework for Interpreting Recorded Human History (Cambridge: Cambridge University Press, 2009); Sidney Tarrow and Charles Tilly, 'Contentious politics and social movements', in Charles Boix and Susan C. Stokes (eds), The Oxford Handbook of Comparative Politics (Oxford: Oxford University Press, 2007).

${ }^{32}$ James D. Fearon, 'Ethnic and cultural diversity by country', Journal of Economic Growth, 8:2 (2003), pp. 195-222; Matthias Basedau, Gero Erdmann, Jann Lay, and Alezander Stroh, 'Ethnicity and party preference in sub-Saharan Africa', Democratization, 18:2 (2011), pp. 462-89.

${ }^{33}$ Jessica Piombo, 'Political parties, social demographics and the decline of ethnic mobilization in South Africa, 1994-99', Party Politics, 11:4 (2005), pp. 447-70.

${ }^{34}$ Muller, 'Parish pump politics'.

${ }^{35}$ Leonardo Rafael Arriola, 'Patronage and political stability in Africa', Comparative Political Studies, 42:10 (2009), pp. 1339-62; Francois, Rainer, and Trebbi, 'How is power shared in Africa?'; Alex M. Kroeger, 'Dominant party rule, elections and cabinet instability in African autocracies', British Journal of Political Science, 50:1 (2020), pp. 79-101.

${ }^{36}$ Felix Haass and Martin Ottmann, 'Profits from peace: The political economy of power-sharing and corruption', World Development, 99 (2017), pp. 60-74.

${ }^{37}$ Nicolas Van de Walle, 'Presidentialism and clientelism in Africa's emerging party systems', The Journal of Modern African Studies, 41:2 (2003), pp. 297-321; Bratton and Van de Walle, 'Neopatrimonial regimes and political transitions in Africa'; Shaheen Mozaffar, James R. Scarritt, and Glen Galaich, 'Electoral institutions, ethnopolitical cleavages, and party systems in Africa's emerging democracies', American Political Science Review, 97:3 (2003), pp. 379-90; Daniel N. Posner, 'Measuring ethnic fractionalization in Africa', American Journal of Political Science, 48:4 (2004), pp. 849-63.

${ }^{38}$ Robert H. Bates, 'Modernization, ethnic competition, and the rationality of politics in contemporary Africa', in Daniel Rothchild and Victor A. Olurunsola (eds), State Versus Ethnic Claims: African Policy Dilemmas (New York: Routledge, 1983), p. 164 .

${ }^{39}$ Francesco Caselli and Wilbur John Coleman II, 'On the Theory of Ethnic Conflict', Working Paper No. 12125 (National Bureau of Economic Research, 2006).
} 
In turn, voters support parties that represent interests of their politically-relevant identity group and exclude others, ${ }^{40}$ allowing leaders and elites to frame the stakes of political contest in often ethno-regional terms that emphasise reciprocity. ${ }^{41}$ These explanations suggest that representative elites can claim to 'have the support' of their communities and use votes and group size as a form of political leverage. While ethnic associations between elites and groups can confer an automatic legitimacy due to a 'constituent pay off, appeals to bloc interests are rarely a sole or consistent motivator in political support. Further, the degree of exchange between representation and patronage allocation is contested, ${ }^{42}$ as resources generally remain in elite hands and do not extend out past a small circle of followers. ${ }^{43}$ Yet senior elite representation is necessary for any possible return on political influence as few other equitable, accessible opportunities are available for groups.

To return some amount of favour and rents to their constituent community, elites must climb the political hierarchy and control the distribution of patronage opportunities. To do so, subnational elites leverage their ethnic, regional, or financial associations in their transaction with regime leaders for positions. Relying on the loyalty principle, any elite and group benefiting from government positions may be less likely to upset the regime and, only under extreme circumstances, destabilise a leader. Access to positions is so crucial that included elites are wary of jeopardising their privileged position and rarely push for political reform, and even opposition politicians frequently accept offers for inclusion from the regime. ${ }^{44} 45$

\section{Representation vs malapportionment tactics}

Representation through senior government appointments can assess how elites and groups are positioned in a regime at any time. There are at least two ways to integrate and measure elite and group levels of power: any appointed position constitutes a claim of representation in national government, while the number and quality of positions allows for an assessment of proportional power between elites and groups. Leaders both include elites in senior positions to sustain high levels of group representation, and manipulate elites and group power through the distribution of appointments. There is an intricate logic to accommodation and inclusion that is both transactional and increasingly formal: leaders arrange the distribution of offices and associated rents, and these exchanges are the main ways to secure commitment between the elite and the leader. ${ }^{46}$ Elites navigate these systems and compete for positions internally by maximising their community leverage, regional affiliations, socioeconomic ties, and ability to suppress threats. Groups and their associated elite representatives differ in their comparable political weight, and leaders recognise and manipulate those variations in elite leverage for their benefit, through exaggerating or limiting their authority, or by taking advantage of intra-elite competition.

\footnotetext{
${ }^{40}$ Kimuli Kasara, 'Tax me if you can: Ethnic geography, democracy, and the taxation of agriculture in Africa', American Political Science Review, 101:1 (2007), pp. 159-72.

${ }^{41}$ Chabal and Daloz, Africa Works; Stephen N. Ndegwa, 'Citizenship and ethnicity: An examination of two transition moments in Kenyan politics’, American Political Science Review, 91:3 (1997), pp. 599-616.

${ }^{42}$ Francois, Rainer, and Trebbi, 'How is power shared in Africa?'.

${ }^{43}$ Van de Walle, 'Presidentialism and clientelism in Africa's emerging party systems'; Nicolas Van de Walle, 'The institutional origins of inequality in sub-Saharan Africa', Annual Review of Political Science, 12 (2009), pp. 307-27; Vicky Randall, 'Political parties in Africa and the representation of social groups', in Matthias Basedau, Gero Erdmann, and Andreas Mehler (eds), Votes, Money and Violence: Political parties and elections in sub-Saharan Africa (Uppsala: Nordic African Institute, 2007), pp. 82-104.

${ }^{44}$ Bratton and Van De Walle, 'Neopatrimonial regimes and political transitions in Africa'; George K. Kieh Jr, 'The "hegemonic presidency” in African politics', African Social Science Review, 9:1 (2018), pp. 36-51; Chabal and Daloz, Africa Works; Arriola, 'Patronage and political stability in Africa'; Arriola and Johnson, 'Ethnic politics and women's empowerment in Africa'.

${ }^{45}$ Examples are alliances between Kenyatta (Kikuyu) and Ruto (Kalenjin) in Kenya's Jubilee Coalition; the coalition between President Ouattara (northerner) and former President Konan Bedie (Baule) in Ivory Coast.

${ }^{46}$ Haber, 'Authoritarian government'; Magaloni, 'Credible power-sharing'.
} 
Through appointing elites to positions in often very sizeable cabinets, leaders create multiple ethno-political configurations. ${ }^{47}$ Regimes that are inclusive and score highly on ethno-political representation may have a malapportioned - or imbalanced - government where one or a few ethno-regional groups have a 'disproportionate' share of cabinet positions. On the other hand, an exclusive regime with low levels of cross-group representation may distribute power equally across elites that are included in government, favouring none.

Why generate an imbalance among included senior elites? Leaders must both hold a coalition together but not advantage any potential threats. Ruling coalitions in which power is dispersed and balanced among senior members can limit the autonomy of the incumbent and lead to political gridlock. ${ }^{48}$ There are several ways that regimes actively distort this body to their benefit: they can 'pack' the cabinet, limiting the power of strong, potential challengers by giving positions to elites from many small communities. The appointment of small group elite representatives in cabinet can rarely be explained by political-demographic leverage; instead, growing the cabinet through short-term positions for small groups enhances a leader's senior support base through 'useful' alliances. These appointments reinforce the loyalty principle and allow regimes to appear 'inclusive'. Regimes also 'counterbalance', creating multiple versions of the same department or positions within government to keep possible competitors weak and disorganised, while creating new allied recipients of patronage. ${ }^{49} 50$ Regimes further bias representation by letting positions accrue to powerful elites who represent strong independent communities. The support of these elites and groups can be more important to capture than the support of those with weaker constituencies, as long as their local authority is contained.

Countries that are inclusive may have a highly imbalanced government where one or a few groups have a 'disproportionate' share of cabinet positions. Many strategies may disproportionately benefit a leader's co-ethnics by prioritising the allocation of key government positions, or conversely may limit co-ethnic power because of the guaranteed support of that constituency. ${ }^{51}$ These practices can involve the co-option of potential rivals into government with mutually beneficial arrangements, in practices known as 'coup proofing'. Yet, supporting rivals as a tactic for sustained rule ${ }^{52}$ is overstated in research ${ }^{53}$ as the imbalance of senior elites is accomplished through multiple, volatile, and often simultaneous strategies. Elites representing large and stronger groups tend to have an imbalanced share of allocated positions, and have more volatile appointments compared to groups of smaller sizes. ${ }^{54}$

Figure 1 is a graphical illustration of two hypothetical configurations of a state with multiple ethnic groups of relatively equal size. Figure 1A represents an ethnically inclusive regime, where most ethnic groups, except one (Group 6), are included within government. Yet, this regime has a malapportioned cabinet, where Group 1 holds dominant power. Tanzanian coalitions represent this model: Tanzania has more than 120 distinct ethno-regional groups and a reputation of

\footnotetext{
${ }^{47}$ Francois, Rainer, and Trebbi, 'How is power shared in Africa?'; Arthur A. Goldsmith, 'Risk, rule and reason: Leadership in Africa', Public Administration and Development, 21:2 (2001), pp. 77-87; Mozaffar, Scarritt, and Galaich, 'Electoral institutions'.

${ }^{48}$ Carl A. Le Van, 'Power sharing and inclusive politics in Africa's uncertain democracies', Governance, 24:1 (2011), pp. 31-53; Philip Roeder, 'Power dividing as an alternative to ethnic power sharing', in Philip Roeder and Donald Rothchild (eds), Sustainable Peace: Power and Democracy after Civil Wars (Ithaca, NY: Cornell University Press, 2005), pp. $51-82$.

${ }^{49}$ Haber, 'Authoritarian government'.

${ }^{50}$ This may explain why several ministries attending to, for example, 'youth' and 'forests' simultaneously and intermittently appear in African cabinets.

${ }^{51}$ Kasara, 'Tax me if you can'.

${ }^{52}$ Roessler, 'The enemy within'.

${ }^{53}$ Michael Albertus, 'Cabinet Volatility Under Dictatorship and Democratic Transition' (2012), available at: \{https://ssrn. com/abstract=1913846\} accessed 15 April 2020.

${ }^{54}$ Raleigh and Wigmore-Shepherd, 'Elite coalitions and power balance across African regimes'.
} 
A: High Representation Regime, Malapportioned Cabinet
B: Low Representation Regime, Well-apportioned Cabinet
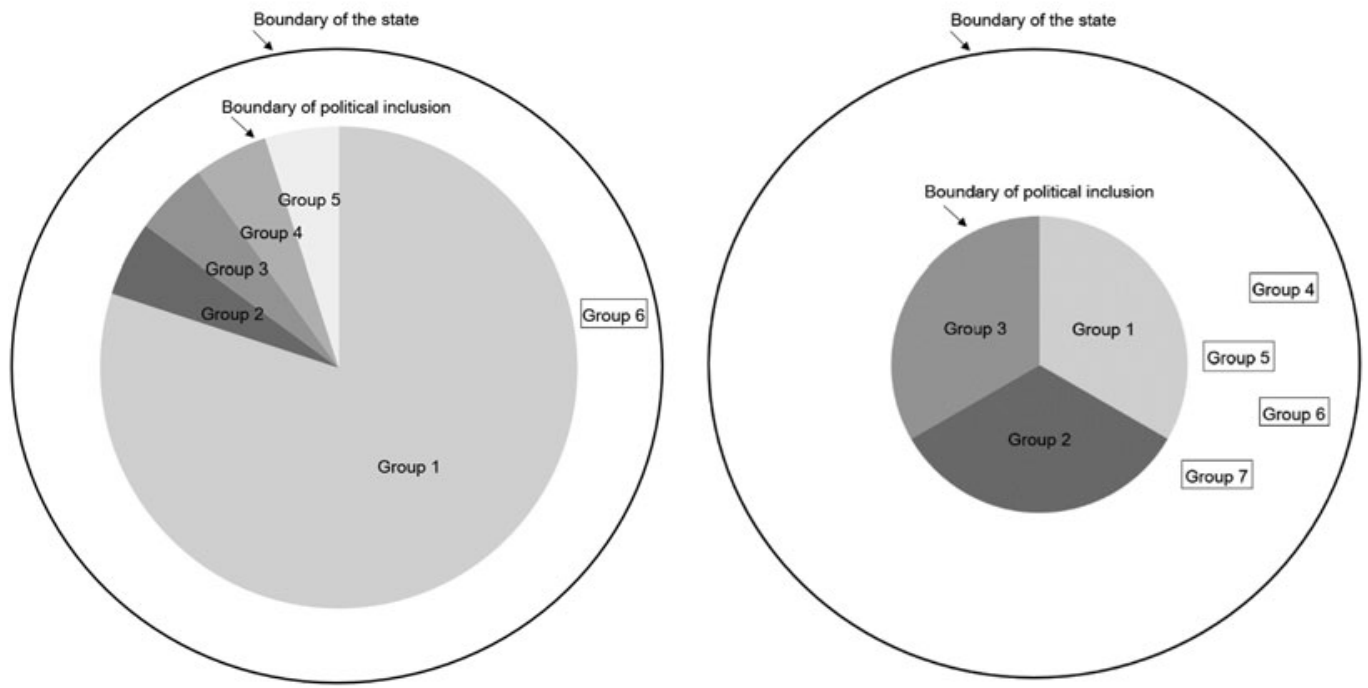

Figure 1. Ethno-political configurations of the state.

Notes: Solid circle represents the territorial boundary of the state. Shaded circle represents the boundary and size of political representation. Each segment within the shaded circle represents the proportion of cabinet positions held by an ethnic group.

ethnically inclusive governance; yet, in some periods, members of Chagga and Hehe groups have taken up almost half of cabinet minister posts between them. This allows leaders to claim widespread representation, while manipulating the power distribution to sustain the regime. By contrast, Figure 1B represents an ethnically exclusive regime, where Groups 4-7 are excluded from participation in central government. It has a well-apportioned cabinet, where three included ethnic groups equally divide executive power positions. Here, representation is manipulated to the needs of powerful social groups and elites. ${ }^{55}$ Both examples are common results of different accommodation strategies practiced between regimes and elites. Both scenarios suggest a more complex representation calculus underlying African political systems, with distinct results for elite competition.

In short, there are many aspects of political survival that require manipulation at the senior scale $^{56}$ and result in inclusive coalitions that are neither fair nor balanced. Consequently, African regimes are inclusive, unbalanced power systems where a skewed distribution of positions and material benefits is accrued by the leader and select benefactors. The effect is to stabilise the regime through promoting and rewarding transactional power politics. ${ }^{57}$ Multiple, concurrent practices are at play at the senior level to assure leader survival and opponent suppression: strong elites may be integrated but sidelined, cabinet sizes may grow to dilute the effect of strong

\footnotetext{
${ }^{55}$ Mushtaq H. Khan, 'Power, pacts and political settlements: A reply to Tim Kelsall', African Affairs, 117:469 (2018), pp. 670-94; Tim Kelsall, 'Thinking and Working with Political Settlements', Working Paper No. 451 (London: Overseas Development Institute, 2016), available at: \{https://www.odi.org/sites/odi.org.uk/files/resource-documents/12520.pdf\} accessed 14 October 2019.

${ }^{56}$ Josef Woldense, 'The ruler's game of musical chairs: Shuffling during the reign of Ethiopia's last emperor', Social Networks, 52 (2018), pp. 154-66.

${ }^{57}$ Beatriz Magaloni and Ruth Kricheli, 'Political order and one-party rule', Annual Review of Political Science, 13 (2010), pp. 123-43.
} 
ministers, multiple ministries for the same issue may occur, etc. These practices can result in the skewed distribution of material benefits to a combination of groups. ${ }^{58}$

Specific institutional arrangements, including the number of elites, groups, and the composition of coalitions that sustain a regime, produce variable degrees of political competition, representation, and stability in African politics. As leaders selectively accommodate and co-opt elites through the appointment process, more subnational bargaining, competition, and fragmentation occurs over access to state power and resources. ${ }^{59}$

\section{Explaining how politics and political violence are connected}

Domestic power distributions create variable threats to regimes and distinct logics for political violence. High representation rates should decrease violence against the state, but high malapportionment rates should increase violence against both the state and other powerful elites and groups as they compete with each other. The underlying emphasis in this set of arguments is that the powerful - not the powerless - engage in violence. Acquiring, keeping, and consolidating power and positions are the motivations for political violence in a regime characterised by inclusivity and competitive clientelism.

Current conflict research is often predicated on an assumption that violence against the state comes from groups excluded from senior positions, and marginalised groups are three times more likely to rebel than do included groups. ${ }^{60}$ Further, relatively wealthy or poor excluded groups are more likely to engage in armed conflict than are those of average wealth. ${ }^{61}$ Anti-state violence is indeed most common in governments characterised by widespread exclusions: rebel violence is most likely to occur in non-democratic systems with small ruling coalitions with little opportunity to politically engage, where armed rebellion presents a legitimate and necessary strategy to overthrow regimes. ${ }^{62}$ Taken together, these studies indicate that ethnic exclusion increases the likelihood of violence motivated by removing the executive and recasting power distributions. By taking advantage of a grievance motivation, excluded groups mobilise to challenge the incumbent and ultimately redress their political status. As enduring proof of this causal relationship, increasing representation across groups should lead to a decrease in this form of political violence. This leads to the first hypothesis:

H1: Higher levels of ethnic representation in senior government positions will decrease levels of anti-state violence.

We argue that high representation levels create alternative logics and forms of political violence. Whereas exclusive politics motivate the threat that marginalised groups present to the state, inclusive politics recasts political competition risks. For regimes, inclusion is a policy of risk management - not risk mitigation - as the composition of included elites is designed to deal with particular internal threats, such as coups, ${ }^{63}$ electoral challenges, ${ }^{64}$ and competition against the government. But internal power holders are still the greatest risk to leaders in

\footnotetext{
${ }^{58}$ Arriola, 'Patronage and political stability in Africa'; Bayart, The State in Africa; Van de Walle, 'Presidentialism and clientelism in Africa's emerging party systems'.

${ }^{59}$ Dawn Brancati, 'Constituency-Level Elections (CLE) Dataset' (New York, 2007), available at: \{http://www.cle.wustl.edu\} accessed 14 October 2019; Chabal and Daloz, Africa Works; Raleigh, 'Pragmatic and promiscuous'.

${ }^{60}$ Cederman, Wimmer, and Min, 'Why do ethnic groups rebel?'.

${ }^{61}$ Lars-Erik Cederman, Nils B. Weidmann, and Kristian Skrede Gleditsch, 'Horizontal inequalities and ethnonationalist civil war: A global comparison', American Political Science Review, 105:3 (2011), pp. 478-95.

${ }^{62}$ Hyun Jin Choi and Dongsuk Kim, 'Coup, riot, war: How political institutions and ethnic politics shape alternative forms of political violence', Terrorism and Political Violence, 30:4 (2018), pp. 718-39.

${ }^{63}$ Roessler, 'The enemy within'.

${ }^{64}$ Chabal and Daloz, Africa Works.
} 
autocracies or transitioning democracies, ${ }^{65}$ and adding more elites to senior positions can exacerbate those risks by introducing competitors willing to use violence.

Competition between the powerful for access to positions is the basis for 'inclusive conflict'. Inter-elite contestation is a likely outcome of the accommodation process within systems where political office has redistributive implications. ${ }^{66}$ Elites may engage in violence against an opponent who is often within the same political party or identity group. They may also target state agents to influence their bargaining position for inclusion. ${ }^{67}$ In this reading, violence is a strategy to gain and sustain leverage, and it emanates from the competition between politically viable blocs and their representatives.

Many of the determinants for positions and authority are set: elites have established community leverage, their formal power is a function of their office, and their influence is relative to others. To influence their leverage, bargaining position, claim on authority, and competitive edge, elites have incentives to design forms of violence. The outcome of competitive violence is a reordering of the elite class, and this initiates periods of bargaining. Leaders encourage a zero-sum competition between elites, and between the regime and elites, and may reward those who wield violence successfully by appointing them to more senior positions. In using violence, elites are modelling their dominance and authority over other elites, indicating how much of a potential threat they are, and securing their leverage. Even if elites using violence are not successful, there are rarely consequences for engaging in conflict, so elites can pursue those strategies with impunity. This violence is 'costless' to the winning elites, and a price of engagement for many other elites.

The level of competition is determined by imbalance rates among the included senior elites and groups. In an inclusive but imbalanced regime, senior elites are in competition for positions and power with leaders and with each other. Violence is expected to increase with 'malapportionment' of senior government positions where one, or a few groups, are dominant enough to secure more state power and resources. In some cases, underrepresented groups (that is, groups whose proportional share of cabinet positions is less than their population weight) may challenge the state through personal armies to secure greater access to government or initiate bargaining with the leader. Alternatively, over-represented groups may use violence to protect their favoured positions. In other cases, overrepresented groups and elites use violence to stifle the influence of internal competitors or other strongly represented groups.

Violence by non-state groups in aid of political elite competition is not designed to replace the leader, but can lead to the replacement of other elites. For that reason, it requires a level of precise targeting both in time and in victims. As noted in recent research about the rise and now dominance of militias in developing and democratising states, elites use these armed non-state groups to pursue violent agents and keep loose affiliations with often ethno-regionally recruited violence agents for use in specific circumstances. ${ }^{68}$ The violence that these groups engage in can vary substantially from pitched battles between militias belonging to political elites and government agents including the president; ${ }^{69}$ harassment of voters and other elite supporters; killing civilians in opposing communities; etc. The violence can take a myriad of forms in part because of the relationship between the elite patrons and the violent groups: these relationships are transactional, ${ }^{70}$ intermittent, and 'outcome focused' in order to maximise the elite's distance and minimise their

\footnotetext{
${ }^{65}$ Haber, 'Authoritarian government'; Bruce Bueno De Mesquita, Alastair Smith, Randolph M. Siverson, and James D. Morrow, The Logic of Political Survival (Cambridge, MA: MIT Press, 2005); Georgy Egorov and Konstantin Sonin, 'Dictators and their viziers: Endogenizing the loyalty-competence trade-off, Journal of the European Economic Association, 9:5 (2011), pp. 903-30.

${ }^{66}$ Jennifer Gandhi and Ellen Lust-Okar, 'Elections under authoritarianism', Annual Review of Political Science, 12 (2009), pp. 403-22; Arriola and Johnson, 'Ethnic politics and women's empowerment in Africa'.

${ }^{67}$ See 'political marketplace' arguments by De Waal, The Real Politics of the Horn of Africa.

${ }^{68}$ Raleigh, 'Pragmatic and promiscuous'.

${ }^{69}$ Ibid.

${ }^{70}$ De Waal, The Real Politics of the Horn of Africa.
} 
responsibility. ${ }^{71}$ This form of conflict group and modality of violence has become dominant across Africa, ${ }^{72}$ largely in line with changes to national level elite integration and increased competition between the powerful. This leads to the second hypothesis:

H2: Higher levels of malapportionment in senior government positions will increase the number of violent acts by non-state groups against (a) state forces and (b) other non-state armed groups.

To illustrate the real-world implications of these practices and how malapportionment is linked to conflict rather than low representation, consider examples demonstrating that some of the continent's most prolific conflicts did not emerge from exclusion, but elite-group imbalances at senior scales. In Burundi during the 1990s, the Hutu majority had representatives at the senior regime level, but the Tutsi minority (under 10 per cent of the population) elites dominated government and sought to maintain almost complete control over the regime, seats, and resources. ${ }^{73}$ As a result of 'elite maintenance', a caste system developed, where violence emanated from both populations. Yet, after more than a decade of fighting, from 1993 onwards, the current government redressed the prewar political castes by introducing new, unavoidable, vulnerabilities: currently, in national and local government, seats are held by both Hutus and Tutsis with a 60-40 per cent split. This is an under-representation of the Hutu population (90 per cent of the population) and an over-representation of the Tutsis (10 per cent of the population). In part to redress their positions in power, Burundi's multiple pro-Hutu/CNDD militias operate across the state, and are linked to the interests of elites at senior levels of the government. ${ }^{74}$

Another example is the recent rise of Ethiopian violence. For several years, Oromo militias sought to challenge their limited influence in government, and the dominance of smaller but far more powerful groups in the coalition-based system. ${ }^{75}$ The Oromo are Ethiopia's largest group, and before the ascension of Prime Minister Abiy Ahmed in 2018, their political influence was muted. Armed groups claiming to be representing this community engaged consistently with the government, as did widespread demonstrators throughout 2014-17. The smaller Tigrayan and Amhara groups had significant powers and senior positions in the regime and its military apparatus since 1991, yet the influence of both groups decreased as Oromo political figures and security personnel - as well as representatives from the remaining groups in Ethiopia's federation - began to populate the senior scales. In response to these groups experiencing a decrease in power to largely proportional levels, an attempted coup in 2019 was led by Amhara members of the Ethiopian government, and Tigrayan based violence occurred in late 2020 as that minority contested their level of influence in the regime (ACLED, 2019).

\section{Research design}

\section{Assessing elite power and distributions}

Previous attempts to capture African representation have relied on lists of ethnic communities and their demographic size, expert opinion on aggregated group roles in

\footnotetext{
${ }^{71}$ National Cohesion and Integration Commission - Kenya, 'The Impact of Organized Gangs on Social Cohesion in Kenya: Policy Options', available at: $\{$ https://www.cohesion.or.ke/index.php/resources/policies-and-regulations?download=27:policybrief-on-impact-of-gangs-on-cohesion $\}$ accessed 1 May 2020; Global Initiative, 'The Politics of Crime: Kenya's Gang Phenomena', available at: \{https:/globalinitiative.net/wp-content/uploads/2020/11/The-politics-of-crime-Kenyas-GangPhenomenon_GITOCESAObs.pdf\} accessed 1 May 2020.

${ }^{72}$ Hyun Jin Choi and Clionadh Raleigh, 'Dominant forms of conflict in changing political systems', International Studies Quarterly, 59:1 (2015), pp. 158-71.

${ }^{73}$ Peter Uvin, 'Mass violence in Burundi and Rwanda: Different paths to similar outcomes', Comparative Politics, 35:2 (1999), pp. 253-71.

${ }^{74}$ FIDH, 'Repression and Genocidal Dynamics in Burundi', available at: $\{$ https://www.fidh.org/IMG/pdf/burundi_report_english-2.pdf\} accessed 27 April 2020.

${ }^{75}$ International Crisis Group, 'Keeping Ethiopia’s Transition on the Rails' (2019), available at: \{https://www.crisisgroup. org/africa/hornafrica/ethiopia/283-keeping-ethiopias-transition-rails\}.
} 
government, ${ }^{76}$ linguistic group numbers, ${ }^{77}$ and distinctions on the scale of political group identity. ${ }^{78}$ No data measured representation for a defined scale of formal, dynamic power such as the executive or legislative branches. Recently, scholars amassed cabinet data for consistent and transparent representation information as 'a cabinet minister in Africa is considered 'a kind of super representative $^{79}$ expected to speak for the interests of co-ethnics as well as channel resources to them'. ${ }^{80}$ Cabinets are the locus of political decision-making and patronage opportunities from which the public may gain benefits. Appointments are a public commitment, as a minister's identity is usually open knowledge, ${ }^{81}$ and the positions indicate the leader and elites' ability to represent and deliver for alliances. ${ }^{82}$ Cabinets suggest executive representation decisions because ministers are a collection of constituency representatives whose inclusion is deemed necessary for the continuation of the regime. ${ }^{83}$ As key strategic transactions, "incumbents co-opt "big men", the influential politicians who can activate their own personalized patron-client networks to recruit supporters or deliver votes on behalf of government'. ${ }^{84}$

Ministerial positions also serve as an important means through which to forge an intra-elite bargain shaped as the leader determines necessary. ${ }^{85}$ In short, cabinet positions are designated by the leader and serve as a direct, identifiable manifestation of accommodation and negotiation politics for elites who, in turn, offer a bridge between regimes and groups. Cabinet positions and ministers are not the sole way in which representation can be measured, but it stands as one of the most comprehensive measures of formal political power ascribed to groups and interests.

The size of cabinet and composition of positions reflects the heterogeneity of the state, and can be a gauge of relationships between leader, elites, and groups. Appointments are a far more accurate valuation of authority and power, because they provide an absolute and relative assessment of each elite and group's definite presence and political 'weight' in government. Appointments can identify which people and groups have inner circle or continuously stable positions and which are in the peripheral positions of great volatility. Rather than relying on an impression or illusion of group power, appointments can confirm how groups or regions are 'relevant' in a political environment. By using individuals and tying their presence and position to the locations and ethnic groups to which they belong, the level of representation at both group and geographic levels, simultaneously and dynamically, is a direct measure of elite power distribution over time.

\section{ACPED}

ACPED tracks the presence, position, and demographics of ministers within African cabinets for each month from 1997 to the present. ${ }^{86}$ Each minister has a position in a state cabinet at some

\footnotetext{
${ }^{76}$ Andreas Wimmer, Lars-Erik Cederman, and Brian Min, 'Ethnic politics and armed conflict: A configurational Analysis of a new global data set', American Sociological Review, 74:2 (2009), pp. 316-37.

${ }^{77}$ Fearon, 'Ethnic and cultural diversity by country'.

${ }^{78}$ James R. Scarritt and Shaheen Mozaffar, 'The specifications of ethnic cleavages and ethnopolitical groups for the analysis of democratic competition in contemporary Africa', Nationalism and Ethnic Politics, 5:1 (1999), pp. 82-117.

${ }^{79}$ Aristide R. Zolberg, One-Party Government in the Ivory Coast (Princeton, NJ: Princeton University Press, 1969), p. 283.

${ }^{80}$ Arriola, 'Patronage and political stability in Africa'.

${ }^{81}$ Posner, 'Measuring ethnic fractionalization in Africa'; Fearon, 'Ethnic and cultural diversity by country'; Kanchan Chandra, Why Ethnic Parties Succeed: Patronage and Ethnic Head Counts in India (Cambridge: Cambridge University Press, 2004).

${ }^{82}$ Arriola, 'Patronage and political stability in Africa'.

${ }^{83}$ Ibid.

${ }^{84}$ Arriola and Johnson, 'Ethnic politics and women's empowerment in Africa'; Bratton and Van de Walle, 'Neopatrimonial regimes and political transitions in Africa'; Larry Diamond, 'The democratic rollback: The resurgence of the predatory state', Foreign Affairs, 87:2 (2008), pp. 36-48.

${ }^{85}$ Roessler, 'The enemy within'; Bratton and Van de Walle, 'Neopatrimonial regimes and political transitions in Africa'; Rothchild, 'Ethnic bargaining and state breakdown in Africa'; Arriola, 'Patronage and political stability in Africa'.

${ }^{86} \mathrm{ACPED}$ (version 1) includes information on 3,165 individual ministers in 16 African countries. For more details, see Raleigh and Wigmore-Shepherd, 'Elite coalitions and power balance across African regimes'.
} 
point from January 1997 onwards, and is included for the duration of his or her tenure. Each minister's entry has associated information including position(s), status, gender, political party, and ethno-regional background. Party affiliation indicates the political party or group of a minister; ministers with no political affiliation are recorded as 'civil society'. Affiliations may vary over the course of tenure. All data assume that cabinet officers at the national level who claim a party membership, group, and region are representatives of those communities. There is no presumed direct effect of ministerial appointments to citizens and guaranteed return for cabinet representation. These data are a disaggregated, time varying, formalised measure of group representation, as African political regimes are a calculated balancing act by the leader and senior elites.

\section{Representation and malapportionment indices}

We use ACPED to create monthly representation and malapportionment assessments for the following states during the period 1997-2016: Algeria, Cameroon, Central African Republic, Democratic Republic of Congo, Guinea, Ivory Coast, Kenya, Liberia, Mali, Nigeria, Sierra Leone, South Sudan, Tanzania, Uganda, and Zimbabwe. ${ }^{87}$ This sample of 15 African states represents a range of regions, violence rates, and types and ultimately, the continent at large. These countries are neither full-scale democracies nor complete autocracies; they hold elections on a regular basis without massive fraud or intimidation, although democratic procedures are often constrained by abuse of state power (for example, biased media coverage, bribery, harassment of opposition politicians, etc.). ${ }^{8}$ Our argument stipulates that African governance challenges are arising in competitive autocracies and hybrid regimes; the variation in both the type and scale of inclusion and the absence or presence of conflict makes this sample of states a robust test of the hypotheses.

\section{Measure of Representation}

ACPED's representation score compares the aggregated elite composition in cabinet to the ethnic composition of the state. ${ }^{89}$ The representation of a group is measured by the presence or absence of an associated cabinet minister at a given time. Ethno-political groups are identified in an ethnic macro-roster for each state, composed from several sources, including national experts, James R. Scarritt and Shaheen Mozaffar's (1999) list, Ethnologue, and Lars-Erik Cederman, Andreas Wimmer, and Brian Min's (2010) Ethnic Power Relations (EPR) data. Multiple sources reflect the variety of subnational identities that may be politically relevant in states at different time periods. Expert opinion is privileged if a discrepancy between source materials arises. Cabinet ministers are associated with their ethno-political groups. Communities who have a representative through one or more cabinet positions in a given country-month are recorded as 'represented' for the period of appointment(s). The aggregated monthly share of included group populations ${ }^{90}$ is the representation score, summarised by the following notation:

$$
\text { Representation }_{c t}=\sum_{i=1}^{n} y_{i c t}
$$

\footnotetext{
${ }^{87}$ When computing the ethnic measure, we exclude observations for Tunisia and Morocco from our panel, as these states have almost no variation in the ethnic composition of its government.

${ }^{88}$ Levitsky and Way, 'Elections without democracy'.

${ }^{89}$ The entire list of macro groups is available upon request from ACPED.

${ }^{90}$ Levels of population are summed through Ethnologue, ethno-regional and ethno-political existing datasets, media and country information sources, national census data, and population rasters such as Worldpop (for regions). All ethnic and regional entities are ascribed a relative size compared to each other, and tallying to 100 per cent for each country. For more details on the ethnic roster compilation, see Raleigh and Wigmore-Shepherd, 'Elite coalitions and power balance across African regimes'.
} 
'Representation' for state $c$ at time $t$ is the combined population share $(y)$ of represented ethnic groups $i$. The Representation index varies between 0 and 1 ; values near 0 denote high exclusivity, and values near to 1 indicate all ethno-political groups are represented in the cabinet.

\section{Measure of malapportionment}

ACPED's malapportionment measure calculates how cabinet appointments are distributed only among those groups in cabinet. The malapportionment index is calculated using the represented groups in a given state-month, and therefore, it describes how power is distributed across cabinet members. To create this measure, all the identified ethno-regional groups represented by ministers within the cabinet-month are merged with their corresponding ethno-political characteristics.

This measure of malapportionment in the national cabinet is based on previously established methods. ${ }^{91}$ Studies on the electoral system have employed 'disproportionality' measures for describing the deviations resulting from the difference between party votes share and party seats share and other contexts. ${ }^{92}$ ACPED's malapportionment score is a modified version of the 'disproportion' index, popularised by John Loosemore and Victor Hanby ${ }^{93}$ and Michael Gallagher. ${ }^{94}$ It determines the discrepancy between the shares of cabinet positions and the shares of population held by included ethnic groups. Thus, the formula becomes:

$$
\text { Malapportionment }_{c t}=\frac{\left(\sum_{i=1}^{n}\left|x_{i c t}-y_{i c t}\right|\right)}{2}
$$

The malapportionment measure for state $c$ at time $t$ is computed as the summation across all ethnic groups of the difference between $x$, which is the share of the cabinet positions allocated to group $i$, and $y$, which is the share of the population of group $i$ in the total population. The above index ranges between 0 and 1, where 0 denotes a perfectly-apportioned cabinet where the demographic weight of an ethnic group is matched to held seats out of the total size in cabinet, and 1 denotes a highly malapportioned case as one or more groups hold many more positions than their relative demographic weight suggests they should.

\section{Sources of malapportionment}

Lastly, to present a more nuanced picture, we identify potential sources of malapportionment. Based on the relative share of the population and cabinet representation for included groups, we distinguish between four conditions that can contribute, individually or in combination, to high levels of malapportionment:

- Majority group / Underrepresented: A politically relevant majority group that comprises more than 50 per cent of the total population and whose cabinet seat assignments are more than 50 per cent below expected proportion based on demographic size.

\footnotetext{
${ }^{91}$ Otis Dudley Duncan and Beverly Duncan, 'A methodological analysis of segregation indexes', American Sociological Review, 20:2 (1955), pp. 210-17; David Samuels and Richard Snyder, 'The value of a vote: Malapportionment in comparative perspective', British Journal of Political Science, 31:4 (2001), pp. 651-71.

${ }_{92}$ Michael Gallagher, 'Proportionality, disproportionality and electoral systems', Electoral Studies, 10:1 (1991), pp. 33-51; Bernardo Bortolotti and Paolo Pinotti, 'The Political Economy of Privatization' (2003), available at: \{https://ssrn.com/ abstract $=418020\}$ accessed 21 April 2020 .

${ }^{93}$ In his study on the disproportionality of electoral outcome, Gallagher ('Proportionality, disproportionality and electoral systems') uses a least squared version of the Loosemore and Hanby (1971) index to compare vote received and seat allocated to parties.

${ }^{94}$ Gallagher, 'Proportionality, disproportionality and electoral systems'; John Loosemore and Victor Hanby, 'The theoretical limits of maximum distortion: Some analytic expressions for electoral systems', British Journal of Political Science, 1:4 (1971), pp. 467-77.
} 
- Large group / Underrepresented: A group that comprises between 25-50 per cent of the population and whose cabinet seat assignments are more than 50 per cent below expected proportion based on demographic size.

- Small group / Overrepresented: A group that comprises between 5-10 per cent of the population and whose cabinet seat assignments are more than 50 per cent above expected proportion based on demographic size.

- Very small group / Overrepresented: A group that comprises less than 5 per cent of the population and whose cabinet seat assignments are more than 50 per cent above expected proportion based on demographic size.

We create four binary indicators that take the value of 1 if a cabinet in a given month has a specific condition of malapportionment - Majority Under, Large Under, Small Over, or Very Small Over - and 0 otherwise.

Figure 2 offers a detailed picture of the cross-country variation of representation and malapportionment scores by state. Observations located in the bottom-right part of the graph include states characterised by high levels of inclusion and well-apportioned cabinets (low malapportionment). These cases are a contrast to those in the upper left quadrant (for example, Uganda and Liberia), which exclude some segments of their ethnic population and have higher levels of malapportionment. Moving towards the upper right are states with both high representation and malapportionment levels. States such as Tanzania, Cameroon, and Ivory Coast include most ethno-political groups but distort elite power through allocating more positions to some group representatives over others. Most African states are in the bottom right-hand position, indicating that they are inclusive and allocate power proportionally across elites. Yet, there is significant variation over time even within these relatively inclusive, balanced cases. Finally, the Pearson Correlation coefficient between Representation and Malapportionment is not high (-0.163), suggesting that these two measures are not mechanically related to each other.

\section{Remaining model specifications}

This study uses country-months as the unit of analysis. The conflict data come from the Armed Conflict Location and Event Data project (ACLED) ${ }^{95}$ whose political conflict data are distinguished by event characteristics and group(s) participating, with geographical location and date. The dependent variables are the number of conflict events for two distinct types of violence: (1) non-state armed group (rebels or militias) against the state; (2) non-state group against another non-state group. ACLED is the sole conflict data project that allows multiple interactive forms of political violence to be measured during and outside of typical 'civil war' periods in a systematic way.

These conflict event aggregations reflect how African conflict has shifted significantly in recent years. Figure 3 displays the number of violent events associated with three agents of violence in 15 African countries from 1997 to 2016. It shows that the number of political militia events have actually surpassed the number of rebel events since 2007, together with a rise in communal militia activities since 2012. This figure tells us that African political violence now primarily consists of clashes and attacks perpetrated by political and communal militias, rather than being characterised by civil wars fought by rebels and states. Acting as personal armies for politicians (for example, Somali regional militias), militias do not seek to replace the state, but to influence its political trajectory by intimidating voters and rival candidates during election periods (for example, Mungiki in Kenya) or challenging intra-party competitors (for example, Zimbabwean

\footnotetext{
${ }^{95}$ Clionadh Raleigh, Andrew Linke, Havard Hegre, and Joakim Karlsen, 'Introducing ACLED: An armed conflict location and event dataset: Special data feature', Journal of Peace Research, 47:5 (2010), pp. 651-60.
} 


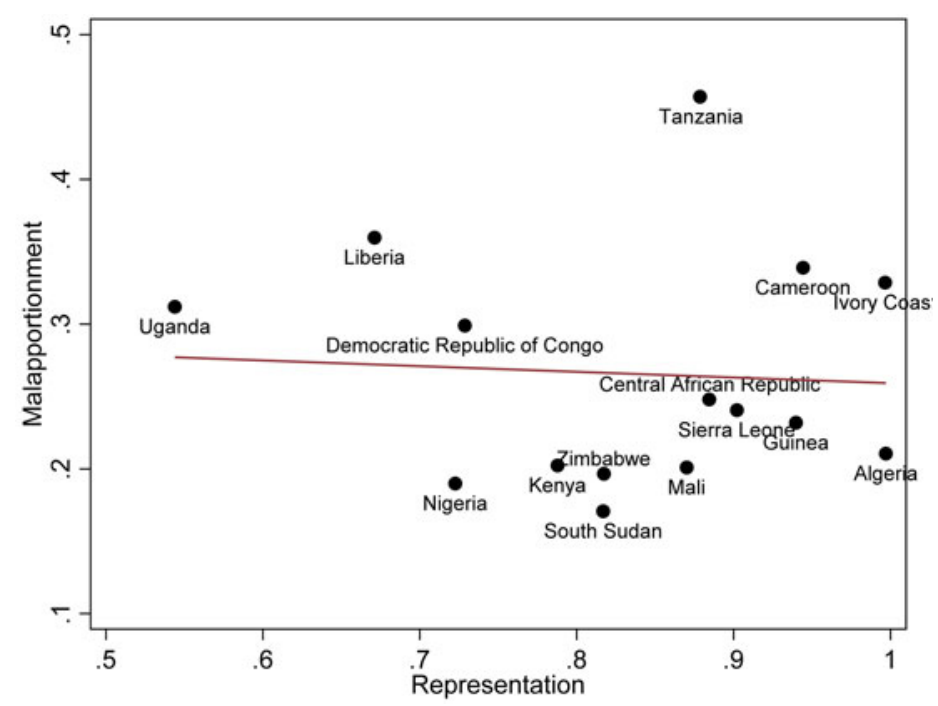

Figure 2. Ethnic measures of Representation and Malapportionment. Notes: Figure 2 displays the average levels of ethnic representation and malapportionment indexes at state level computed using ACPED. All the values are computed for the period 1997-2016, except for South Sudan (2011-16).

ZANU-PF activity). For this reason, the conflicts considered here focus on common agents and forms of political violence but allows for a wide consideration by using all acts involving state forces.

Explanatory variables include measures of ethnic Representation and cabinet Malapportionment derived from ACPED. We also use dummy variables referring to specific conditions of malapportionment, that is, Majority Under, Large Under, Small Over, and Very Small Over. All of these variables are lagged by one month to reduce endogeneity bias, which is ensuring that there are political traits preceding the occurrence of violent events. Nevertheless, we remain concerned that our results might be driven by endogeneity and reverse causality. Thus, we conducted several tests of whether past occurrences of violent events affect representation or malapportionment levels in the present month. If underrepresented groups successfully challenged the state and then attained more senior positions, we should see a decreased malapportionment (or increased representation) score. If those who challenged the state or other elites were punished by the leader, we might expect an increased malapportionment (or decreased representation) score. Neither was the case. We found no significant evidence that present values of malapportionment and representation are influenced by past conflict events. ${ }^{96}$ One possible explanation is that the type of violence examined here - militia violence, in particular - is not designed to replace the leader, and thus is not large or intimidating enough to affect the composition of cabinets in the short term.

We include several control variables to capture factors that are known to influence conflicts through other channels. We control for the number of ministers (Cabinet Size) and discrete ethnicities represented within the cabinets (Ethnicities in Cabinet). A larger number of cabinet ministers is expected to lower the risk of internal revolt (for example, coup d'état) by making the incumbent less dependent on the loyalty of any single elite group. ${ }^{97}$ We also expect that the number of ethnicities in cabinet may correlate with violence independent from power distributions. ${ }^{98}$ Their inclusion enables us to identify the effects of the main explanatory variables of power distribution, while fixing the number of politicians and ethnic groups in the central government. In

\footnotetext{
${ }^{96}$ The results of endogeneity tests are reported in online supplementary material, Table A2.

${ }^{97}$ Arriola, 'Patronage and political stability in Africa'.

${ }^{98}$ Sonia Alonso and Ruben Ruiz-Rufino, 'Political representation and ethnic conflict in new democracies', European Journal of Political Research, 46:2 (2007), pp. 237-67.
} 


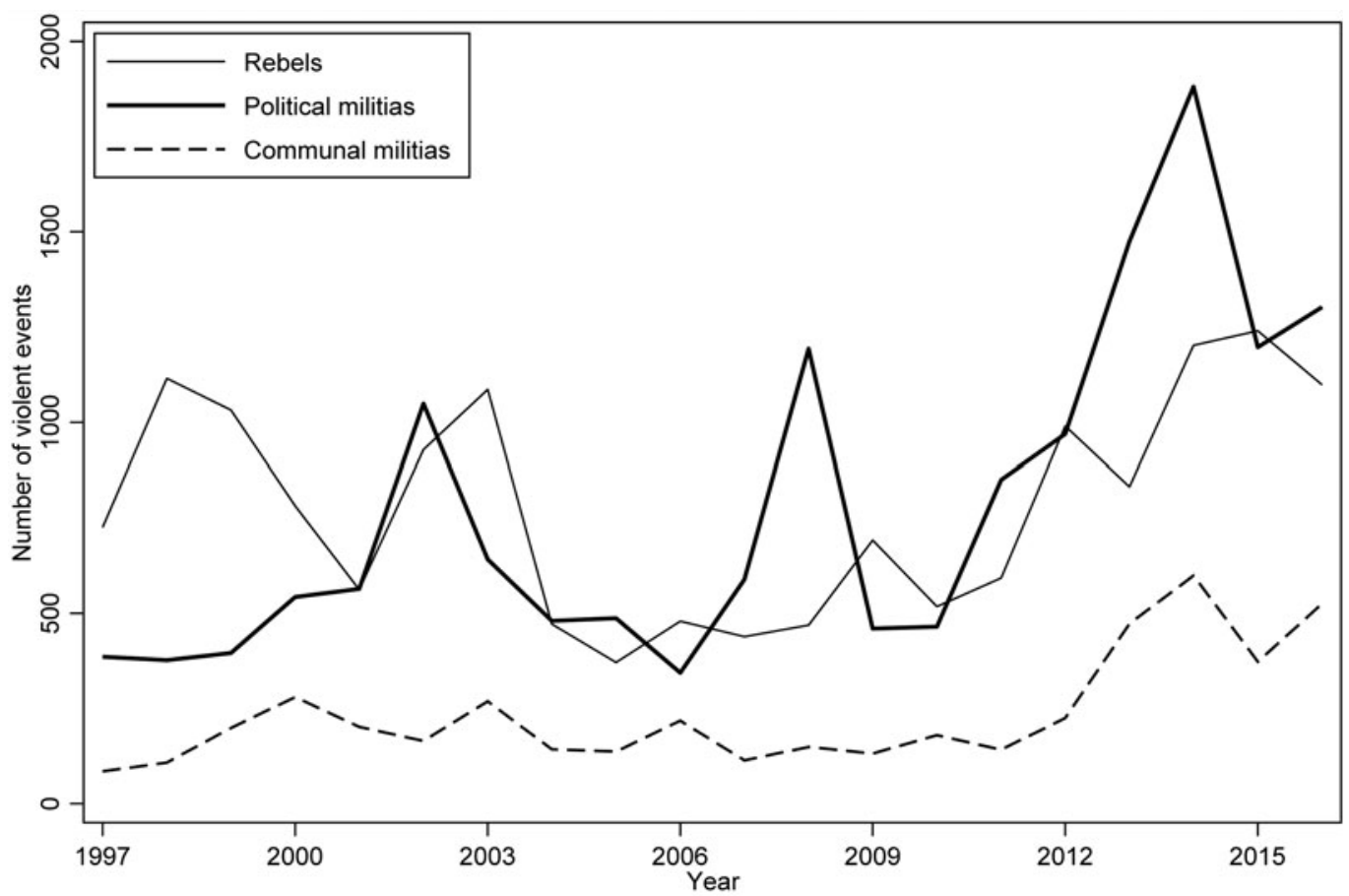

Figure 3. Three agents of political violence in 15 African countries, 1997-2016, based on the ACLED project.

addition, the Democracy variable captures the quality of democracy in African states and has been found to influence the onset and degree of armed conflicts in previous research; ${ }^{99}$ to measure this, we use the index of electoral democracy (Polyarchy index) of the Varieties of Democracy (V-Dem) project. ${ }^{100}$ Lastly, we include the natural log of GDP per capita to control for socioeconomic conditions of the conflict state. ${ }^{101}$ This variable is taken from the World Bank's World Development Indicators. ${ }^{102}$

Table 1 provides summary statistics for all explanatory and control variables. The mean level of representation is 85.5 per cent, providing robust affirmation that African governments generally represent their populations. Yet, representation is volatile and varying. For example, the lowest level of representation is registered for Mali during April 2012 (8 per cent) and April 2011 (15 per cent), which preceded the onset of the civil war that affected the north of the country in 2012. The mean level of malapportionment in African cabinets is equal to 25 per cent, indicating that, on average, 25 per cent of a country's represented ethno-political population are over or underrepresented. The highest malapportionment value (49.8 per cent) of the sample is in Tanzania during August 1998.

\footnotetext{
${ }^{99}$ Paul Collier and Anke Hoeffler, 'Greed and grievance in civil war', Oxford Economic Papers, 56:4 (2004), pp. 563-95; Bethany Lacina, 'Explaining the severity of civil wars', Journal of Conflict Resolution, 50:2 (2006), pp. $276-89$.

${ }^{100}$ Michael Coppedge, John Gerring, Staffan I. Lindberg, Svend-Erik Skaaning, and Jan Teorell, 'Varieties of Democracy: Comparisons and Contrasts', in the Varieties of Democracy (V-Dem) Project (2015); Unlike the Polity IV score of Monty G. Marshall, Ted Robert Gurr, and Keith Jaggers (2011), the V-Dem's Polyarchy index does not include measures of civil violence and/or political terror in its construction.

${ }^{101}$ Information on Democracy and GDP per capita are only available as annual observations and interpolated for monthly periods.

${ }^{102}$ World Bank, 'World Development Indicators', available at: $\{$ https://datatopics.worldbank.org/world-development-indicators/\} accessed 20 April 2020.
} 
Table 1. Summary statistics for explanatory and control variables.

\begin{tabular}{|c|c|c|c|c|}
\hline Variable & Mean & Std Dev. & Min. & Max. \\
\hline \multicolumn{5}{|l|}{ Explanatory variables } \\
\hline Representation $_{\mathrm{t}-1}$ & 0.855 & 0.121 & 0.230 & 1.000 \\
\hline Malapportionment $_{\mathrm{t}-1}$ & 0.247 & 0.076 & 0.047 & 0.498 \\
\hline Majority Under $_{\mathrm{t}-1}$ & 0.069 & 0.253 & 0.000 & 1.000 \\
\hline Large Under ${ }_{\mathrm{t}-1}$ & 0.391 & 0.488 & 0.000 & 1.000 \\
\hline Small Over ${ }_{t-1}$ & 0.418 & 0.493 & 0.000 & 1.000 \\
\hline Very Small Over ${ }_{\mathrm{t}-1}$ & 0.755 & 0.430 & 0.000 & 1.000 \\
\hline \multicolumn{5}{|l|}{ Control variables } \\
\hline Cabinet Size & 29.566 & 6.246 & 1.000 & 48.000 \\
\hline Ethnicities in Cabinet & 8.954 & 3.139 & 1.000 & 18.000 \\
\hline Democracy & 0.392 & 0.119 & 0.151 & 0.677 \\
\hline Log(GDP per capita) & 6.367 & 0.781 & 4.631 & 8.624 \\
\hline
\end{tabular}

A Poisson model with fixed effects tests the hypotheses and accounts for the discrete nature of the conflict variables. ${ }^{103}$ To further control for spatiotemporal factors, we include both country and year fixed effects. Country fixed effects account for state invariant, unobserved characteristics that are likely to influence the average level of conflict within a state, such as historical grievances and geographic characteristics (for example, mountainous terrain, natural resource endowments). Year fixed effects deal with continent-wide temporal trends that may influence dependent variables (for example, drought, financial crisis). Hence, the number of violent events $y_{c t}$ for country $c$ at time $t$ is assumed to have a Poisson distribution with expectation $\mu_{c t}$, given a vector of explanatory and control variables $\mathbf{x}_{c t}$, according to the following log-linear function:

$$
\ln \left(\mu_{c t}\right)=\gamma_{c}+\delta_{t}+\beta \mathbf{x}_{c t}
$$

where $\gamma_{c}$ and $\delta_{t}$ are country and year fixed effects, respectively, and $\beta$ is a vector of parameters to be estimated. All models are estimated with robust standard errors clustered by country.

\section{Results on the allocation of power and conflict}

Table 2 presents coefficients and standard errors from the empirical tests of conflict events for two distinct types of violence: anti-state violence by non-state armed actors (models 1 and 2), and violence among non-state actors (models 3 and 4). In model 1, the impact of ethnic Representation on violence against the state is found insignificant, and with an unexpected positive sign. This result runs contrary to a common view among policymakers and academics that ethnicity-based exclusion from state power is a principal source of civil war (H1). ${ }^{104}$ On the other hand, cabinet Malapportionment is a significant and strong predictor of violence against the state,

\footnotetext{
${ }^{103}$ While Poisson models are not appropriate for modelling over-dispersed count data, Poisson fixed effects estimators with cluster robust standard errors are found to be robust to overdispersion. An alternative to Poisson would be the negative binomial model. However, Allison and Waterman (Paul Allison and Richard Waterman, 'Fixed-effects negative binomial regression models', Sociological Methodology, 32:1 (2002), pp. 247-65 (p. 247)) showed that the conditional negative binomial regression for panel data is 'not a true fixed-effects method' and does not 'control for all stable covariates'. Unconditional negative binomial regression with dummy variables is also vulnerable to biases resulting from the incidental parameters problem. Nevertheless, for robustness concerns, we repeat all the analyses in Table 2 using an unconditional negative binomial model with dummy variables for country and year. The results of robustness tests are reported in the supplementary material Table A2. For more information on Poisson fixed effects estimator, see Colin Cameron and Pravin Trivedi, Regression Analysis of Count Data (2nd edn, Cambridge: Cambridge University Press, 2013), pp. 341-57; Jeffrey Wooldridge, Econometric Analysis of Cross Section and Panel Data (2nd edn, Cambridge, MA: MIT Press, 2010), pp. 755-8. For unconditional negative binomial estimator, see Allison and Waterman, 'Fixed-effects negative binomial regression models'.

${ }^{104}$ Cederman, Wimmer, and Min, 'Why do ethnic groups rebel?'
} 
Table 2. Impact of representation and malapportionment on African political violence.

\begin{tabular}{|c|c|c|c|c|}
\hline \multirow[b]{2}{*}{ Variables } & $(1)$ & $(2)$ & (3) & (4) \\
\hline & \multicolumn{2}{|c|}{ Non-state actors vs Government } & \multicolumn{2}{|c|}{ Violence among non-state actors } \\
\hline Representation $_{\mathrm{t}-1}$ & $\begin{array}{c}0.741 \\
(1.151)\end{array}$ & & $\begin{array}{l}-0.723 \\
(0.575)\end{array}$ & \\
\hline Malapportionment $t_{t-1}$ & $\begin{array}{c}3.196 \\
(1.617)^{\star \star}\end{array}$ & & $\begin{array}{c}2.668 \\
(1.253)^{\star \star}\end{array}$ & \\
\hline Majority Under $_{\mathrm{t}-1}$ & & $\begin{array}{c}1.363 \\
(0.307)^{\star \star \star}\end{array}$ & & $\begin{array}{c}0.943 \\
(0.294)^{\star \star \star *}\end{array}$ \\
\hline Large Under ${ }_{\mathrm{t}-1}$ & & $\begin{array}{c}0.653 \\
(0.289)^{\star \star}\end{array}$ & & $\begin{array}{c}0.520 \\
(0.137)^{\star \star \star}\end{array}$ \\
\hline Small Over ${ }_{t-1}$ & & $\begin{array}{c}0.683 \\
(0.314)^{\star \star}\end{array}$ & & $\begin{array}{l}-0.155 \\
(0.324)\end{array}$ \\
\hline Very Small Over $_{\mathrm{t}-1}$ & & $\begin{array}{c}0.039 \\
(0.227)\end{array}$ & & $\begin{array}{c}1.120 \\
(0.536)^{\star \star}\end{array}$ \\
\hline Cabinet Size & $\begin{array}{c}0.004 \\
(0.019)\end{array}$ & $\begin{array}{c}0.012 \\
(0.018)\end{array}$ & $\begin{array}{l}-0.008 \\
(0.021)\end{array}$ & $\begin{array}{l}-0.013 \\
(0.019)\end{array}$ \\
\hline Ethnicities in Cabinet & $\begin{array}{c}-0.209 \\
(0.075)^{\star \star \star}\end{array}$ & $\begin{array}{c}-0.161 \\
(0.074)^{\star \star}\end{array}$ & $\begin{array}{c}0.026 \\
(0.044)\end{array}$ & $\begin{array}{l}-0.004 \\
(0.050)\end{array}$ \\
\hline Democracy & $\begin{array}{l}-1.963 \\
(2.276)\end{array}$ & $\begin{array}{l}-2.274 \\
(2.497)\end{array}$ & $\begin{array}{c}-5.614 \\
(1.554)^{\star \star \star}\end{array}$ & $\begin{array}{c}-5.302 \\
(1.361)^{\star \star \star}\end{array}$ \\
\hline Log(GDP per capita) & $\begin{array}{c}0.318 \\
(0.621)\end{array}$ & $\begin{array}{c}0.355 \\
(0.630)\end{array}$ & $\begin{array}{l}-0.374 \\
(0.485)\end{array}$ & $\begin{array}{l}-0.389 \\
(0.481)\end{array}$ \\
\hline Country fixed effects & yes & yes & yes & yes \\
\hline Year fixed effects & yes & yes & yes & yes \\
\hline Log likelihood & $-10,297.02$ & $-10,162.42$ & $-5,018.32$ & $-4,947.26$ \\
\hline Number of countries & 15 & 15 & 15 & 15 \\
\hline Number of observations & 3,409 & 3,409 & 3,409 & 3,409 \\
\hline
\end{tabular}

Note: Robust standard errors clustered on country in parentheses. ${ }^{\star} p<.1 ;{ }^{\star \star} p<.05 ;{ }^{\star \star \star} p<.01$ (two-tailed tests).

lending support to H2a. When the score of Malapportionment increases from the minimum (0.047) to maximum (0.498), the number of anti-state violence increases by 323 per cent, holding other variables constant. This is consistent with our expectation that anti-state violence in hybrid regimes will increase because of elite competition or in response to the rising level of ethnic imbalance in senior government positions.

In a further effort to investigate H2a, model 2 introduces four conditions of malapportionment. According to our theory, both under- and over-represented ethnic groups spur anti-state violence: the former may challenge the state to secure greater access to government, while the latter uses violence to reinforce their favoured positions. Indeed, this is what we find. The coefficients range from a low and insignificant 0.039 for very small-overrepresented groups up to a significant 0.683 for small, overrepresented and a highly significant 1.363 for majority, underrepresented groups. The last category is especially conflict prone: having an underrepresented majority in cabinet increases the number of anti-state violence by about 286 per cent, holding other variables constant. On the other hand, a small and insignificant coefficient on Very Small Over suggests that smaller groups are less able to challenge a government due to their limited pool of resources and potential fighters. These results clearly confirm H2a but not H1: Given that African states generally practice inclusive representation today, the main factor in crossnational variation of anti-state violence is not ethnic exclusion but distorted distribution of elite power.

Figure 4, which is based on model 1, plots the predicted number of violent events against the state as a function of Malapportionment, holding other variables at their means. We observe a significant and positive effect of cabinet malapportionment: as the Malapportionment measure gets higher, so does the risk of anti-state violence by non-state armed groups, although the effect is imprecisely estimated for highly malapportioned cabinets. Figure 5, which is based on model 2, 


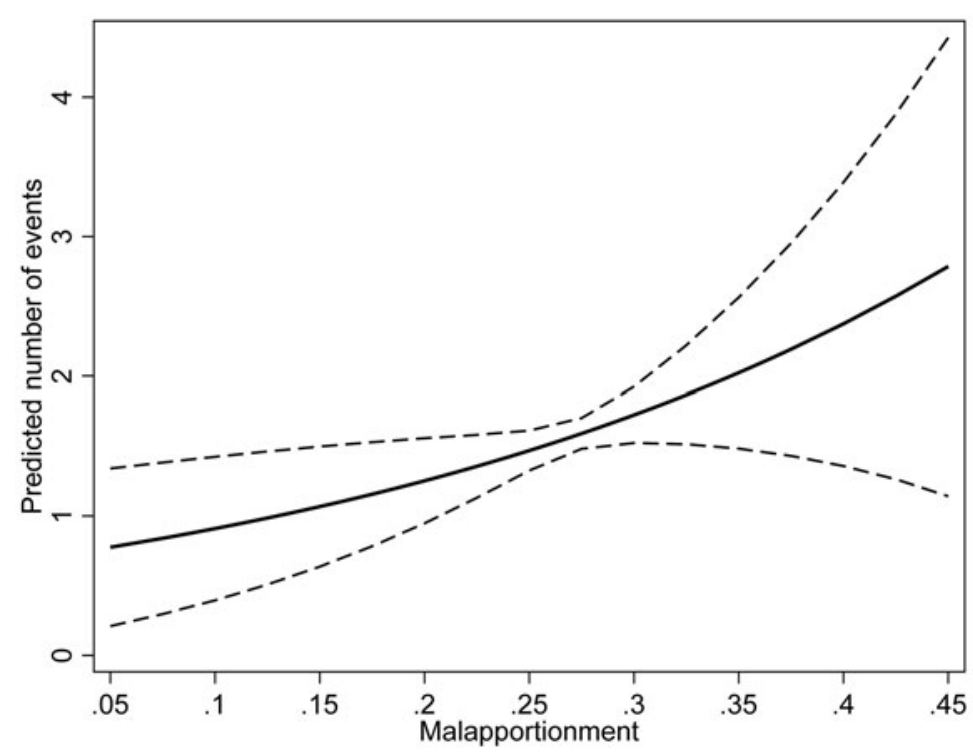

Figure 4. Predicted number of violence against the state (with 95 per cent confidence intervals) as a function of Malapportionment. All other variables are held at their means.

shows the relative differences in predicted number of anti-state violence caused by each condition of malapportionment. The effect of underrepresented majority group is most pronounced: a change in Majority Under from 0 to 1 is expected to increase number of violence by 3.9 times, holding other variables at their mean values.

Shifting our attention from anti-state violence to non-state infighting in model 3, the coefficient for Malapportionment is also positive and statistically significant for violence among nonstate actors, providing support for $\mathrm{H} 2 \mathrm{~b}$. Increasing the Malapportionment score from the minimum to maximum raises the expected violence among non-state actors by about 233 per cent, holding all other factors constant. On the other hand, we do not find any substantive effect of Representation. These results show violent competition among non-state actors is emerging as an alternative modality of political violence in African states, which have ethnically inclusive but malapportioned governments. In model 4, we replace aggregate indices of power distribution with specific conditions of malapportionment. Again, the presence of underrepresented majority and large ethnic groups (Major Under and Large Under) increases the number of violence between non-state groups significantly, in line with $\mathrm{H} 2 \mathrm{~b}$. In addition, the impact of Very Small Over is both large and significant in contrast to its effect on anti-state violence in model 2, suggesting that lower mobilisation capacity does not deter violent infighting among non-state actors.

Figure 6 offers a graphical presentation of how different conditions of malapportionment influence violence among non-state actors. The plots, based on model 4, show that cabinets with an underrepresented majority remain the most fertile condition for intra-elite violence. Also noteworthy is the effect of Very Small Over, which is as large as the effect of Large Under. This analysis provides additional support for H2b. The imbalance of power between two group types generates violent competition between non-state actors: large groups with fewer seats are seeking to redress their limited leverage, while smaller groups with more seats are seeking to secure their level of power within the regime.

Four conditions of malapportionment warrant further explanation. A strategic imbalance emerges when large groups are accorded representation without adequately reflecting their population share. It is often intentional: leaders have the choice to extend the size of cabinet to distribute seats in line with demographic size, or can choose to reduce the seats given to other groups, including significantly-sized groups, small, or very small politically relevant communities. 
Figure 5. Relative differences in predicted number of violence against the state (with 95 per cent confidence intervals) by four conditions of malapportionment. All other variables are held at their means.

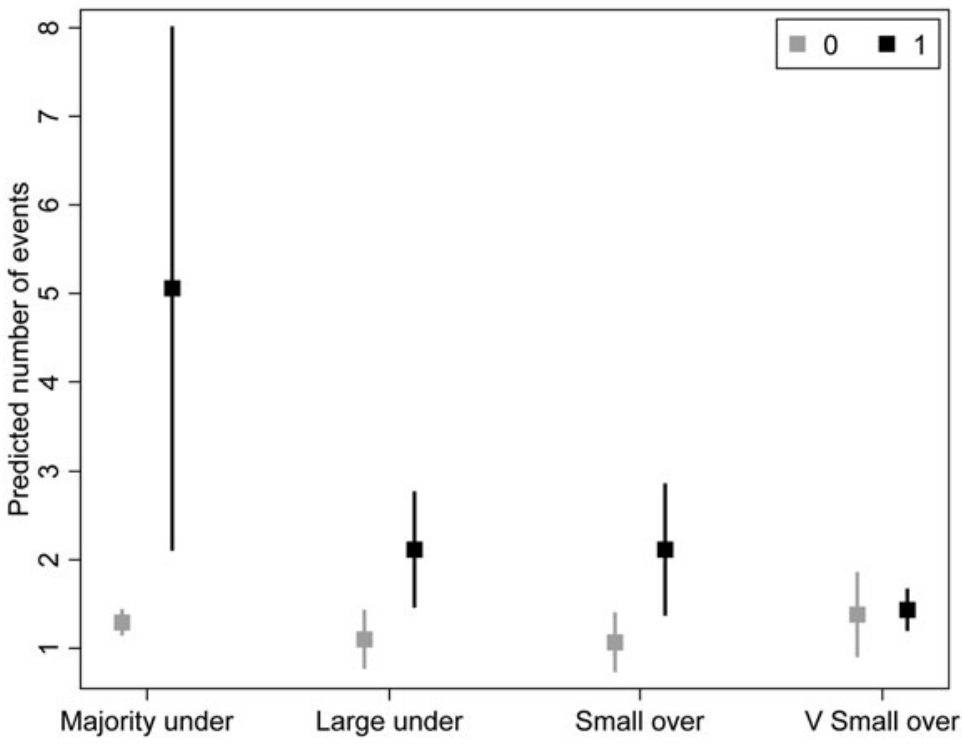

Choosing not to do so reflects that a leader is actively seeking to suppress the influence of large groups, while still nominally representing said communities in cabinet. The seat(s) allocated to large groups may be of high importance, such as finance or foreign ministries. But by limiting the internal strength of a group within cabinet, leaders can suppress challenges that may arise from coordinated internal actions, or place a significant barrier to the coordinated actions across different representative elites and groups. The result is that large groups are represented but have lower levels of relative power within cabinet, and in turn this nullifies an 'exclusion' grievance to motivate large scale conflict against the state, while also suppressing the ability to harness internal cabinet strength to sanction or leverage against the leader. One way to redress this imbalance is to engage in conflict, at low levels, to challenge the state or other overrepresented elites, thereby increasing the 'consequences' of imbalance for the leader. The logic in these circumstances is that a group can raise the cost of being sidelined, over the leader's benefit for doing so.

The control variables provide additional insights. Higher numbers of ethnic groups in cabinet (Ethnicities in Cabinet) significantly decreases violence against the state. This result might suggest that greater inclusivity in cabinet representation decreases the risk of armed rebellion. However, ethnically diverse cabinets are not necessarily inclusive, so the results on the number of ethnicities in cabinet do not provide solid evidence for $\mathrm{H} 1 .^{105}$ In addition, higher levels of electoral Democracy have significant, negative effects on violence between non-state groups while having no significant impact on anti-state violence. Finally, Cabinet Size and GDP per capita fail to exhibit any significant or substantive effects on both types of violence.

Our main findings can be summarised as follows. First, in African polities that generally practice inclusive representation, ethnic exclusion or representation is no longer a significant predictor of anti-state violence. Second, the inequality of power between included groups, rather than ethnic exclusion, is a better predictor of which countries are at risk for political violence. This includes a malapportioned cabinet where one or a few select ethnic groups have dominant influence. Third, the risk of both anti-state violence and non-state groups' infighting is substantially higher for malapportioned regimes where cabinet seats are under-allocated to majority or large ethnic groups.

\footnotetext{
${ }^{105}$ The Pearson correlation coefficient between Representation and Ethnicities in Cabinet is -0.2513 . This correlation depends on the number of possible groups within a state to be potentially included, rather than simply the number in cabinet.
} 


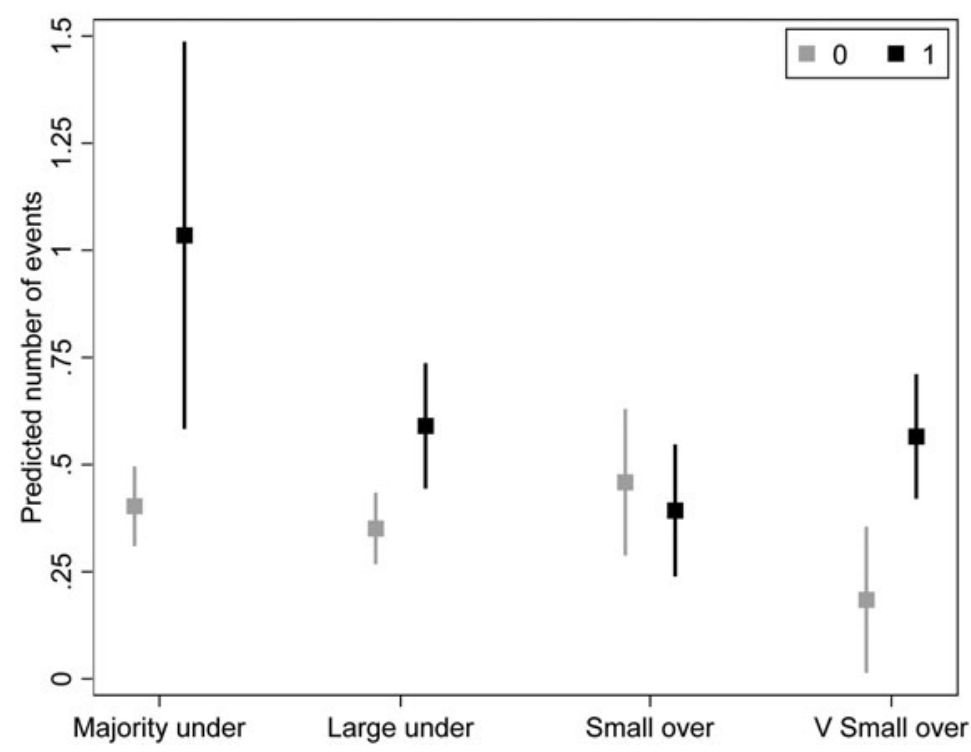

Figure 6. Relative differences in predicted number of violence among non-state actors (with 95 per cent confidence intervals) by four conditions of malapportionment. All other variables are held at their means.

Lastly, it is important to note that these results come with an important caveat: our efforts to capture violent competition between included elites is conducted with aggregate data at the country level. Thus, while we find that imbalanced power in cabinet has the largest effect on the number of violent events, our research design cannot rule out the possibility that some of those events were carried out by excluded groups. Ongoing research will illustrate how relative power shares are associated with intensity, modality, and frequency of violence at the subnational level.

\section{Conclusion}

The political inclusion of ethno-political groups is not an absolute solution for national grievances. Violence is used by included groups and elites to assert their control of the state, and this reinforces that groups in power, rather than out of power, have significant influence on levels of conflict in African countries. Therefore, beyond the knowledge that excluded groups are more likely to rebel, those with state power must be considered when explaining political violence. Domestic politics generates the motivation, agents, and dynamics of political violence, and how leaders manage competing political identities underlies the success or failure of government functions. ${ }^{106}$ As political institutions have changed across Africa, the strategic calculations of leaders and subnational elites have changed to reflect the political contests in new institutions. In turn, conflict has adapted, changing form to fit into the present power contest.

We also argue that the link between conflict and representation has been unduly limited to exclusion and civil wars. But other modalities of political violence have increased, while political inclusion has risen. We find that political violence is widespread across democratising states because of 'competitive clientelism', where elites are vying for senior positions and leaders are seeking to build inclusive ruling coalitions, violence becomes a strategy of negotiation. Organised violence becomes a strategy of elites to increase power, and is directed against regimes and other elites. In competitive clientelism, violent strategies are closely associated with included elites rather than marginalised communities. Pursuing armed, organised violence is a strategy of those with the means and ability to generate significant pressure on the regime; excluded groups

\footnotetext{
${ }^{106}$ Andreas Wimmer, Waves of War: Nationalism, State Formation, and Ethnic Exclusion in the Modern World (Cambridge: Cambridge University Press, 2012).
} 
are limited in their capacity to pursue this option. The contest for power takes place among elite members of an inclusive ruling coalition. To that end, conflict is not due to a breakdown in competitive clientelism: it is often a feature of it.

These findings suggest that power politics, or 'realpolitik' principles, are apt representations of elite competition across African states. Leaders are engaged in a two-level game: they will appoint elites to the cabinet from a large swathe of the population, maximising 'representation' and 'inclusivity' and providing enough rents and positions to potential spoilers. This is necessary for legitimacy, consolidation of authority, and influence across the state. Nevertheless, higher levels of malapportionment in the national cabinet can still increase the risk of violence against the state. 'Dissatisfied' elites may engage in anti-state violence for greater access to state power and resources. Therefore, imbalance in elite representation creates conflict, but rarely challenges leaders.

To conclude, a leader's survival is closely dependent on co-opted subnational elites, but a leader's optimal coalition is not necessarily one that is fairly balanced. Strategies employed to generate a compliant coalition are not likely to be stable or peaceful. Regimes across African states have managed to include great numbers of ethno-political communities, expand and retract cabinets frequently, and withstand variable levels and modalities of political violence, both against the state and between elites. These factors underscore that competitive clientelism is a core feature of African politics. Further, it reinforces the importance of subnational elites as critical political figures within African politics and as objects of study among scholars seeking to understand the changing dynamics of violence across the continent.

Acknowledgements. The authors would like to acknowledge the support of the Horizon 2020 European Research council via Clionadh Raleigh's ERC 'Consolidator' grant. Dr Guiseppe Maggio was central to determining many of the measures for cabinet representation levels, and Stephen Hunt assisted with the final proofs of this article. This research was funded by the Horizon 2020 European Research Council Grant No. 726504 (VERSUS).

Supplementary material. To view the online supplementary material, please visit: https://doi.org/10.1017/ S0260210521000218

Clionadh Raleigh, PhD (University of Colorado, 2007) is a Professor of Political Violence and Geography in the School of Global Studies at the University of Sussex and the Executive Director of ACLED. Her primary research interests are the dynamics of conflict and violence, focusing in particular on the role of formal and informal political structures. Her work is based on African quantitative and qualitative case studies. Author's email: clionadh.sussex@gmail.com

Hyun Jin Choi, PhD (Michigan State University, 2012), is an Associate Professor in the Department of Political Science at Kyung Hee University, Seoul. Professor Choi's research interests fall within the field of civil war, sub-Saharan Africa, and international development. His articles have been published in numerous refereed journals, including Global Environmental Change; International Studies Quarterly; Comparative Politics; and Journal of Conflict Resolution. Author's email: hchoi77@gmail.com

Daniel Wigmore-Shepherd is a PhD graduate of the University of Sussex. His research focused on government composition, elites, and political volatility across Africa. Dr Wigmore-Shepherd currently works in the private sector in survey analysis and polling. Author’s email: danielwigmoreshepherd@gmail.com

Cite this article: Raleigh, C., Choi, H. J., Wigmore-Shepherd, D. 2022. Inclusive conflict? Competitive clientelism and the rise of political violence. Review of International Studies 48, 44-66. https://doi.org/10.1017/S0260210521000218 